\title{
Work Overload, Work-Family Conflict, Family-Work Conflict and Their Effects on Job Embeddedness: The Moderating Role of Coworker Support
}

\author{
Fatima Salam \\ Foundation University Islamabad
}

\begin{abstract}
The study was intended to find out the impact of work overload, work-family conflict and family-work conflict on job embeddedness. For the analysis of the study an aggregate of 250 responses were chosen. Analysis was made through Simple, multiple and moderating regression. Results have shown a substantial influences of work overload and family-work conflict towards job embeddedness. Support of coworker could not moderate any of the proposed relationships.
\end{abstract}

\section{Introduction}

In today's world we observe that there has been a drastic increase of dual-earners and increasing participation of women in the workforce. On the other hand, the business and working environment has become competitive and employees have to work in a turbulent state of affairs. Thus, the work life of all most all employees has become so complex. Traditional gender roles are no longer restricted to everyday jobs like work, housework or childcare (Byron 2005). Growth in global business and technology involved employees of the global firms more into jobs and working hours increased therefore, Flexible work arrangement programs are offered by employers because employees are not sufficiently adept to form a balance between work and family (Masuda et al 2012). Many scholars have highlighted work-family conflict as a peril to organization's productivity, job satisfaction, performance, physical and mental wellbeing and a cause of burnout in employees (Frone, Yardley \& Markel 1997; Adams, King \& King 1996; Schaufeli 2003).Former number of work on WorkFamily conflict point towards a reason for employees' turnover (Eby et. al; Greenhaus, 2001). When an employee goes through problems of work-family conflict and family-work conflict, he eliminates this conflict by withdrawing himself from the job and this compels him on thoughts of intention to leave that organization (Greenhaus et al. 2001). The total loss that an organization has to bear due to employee withdrawal is 17 percent of before tax annual income (Sagie et al. 2002).

Significance of the study:

The existing study signifies a step forward in understanding joint effect of work overload, work family conflict, family work conflict on job embeddedness employees in Pakistan with moderating effect of coworker support. Theory of Job embeddedness is relatively new standpoint in turnover research (Zhang et al 2012; Chiaburu 2010). Felps et. al (2009) have recommended that the importance of coworkers influencing retention and turnover of their fellows has received insufficient consideration. Most of the scholars have focused on hierarchical relationship of supervisor and subordinate while coworker support has received little attention (Bassford and Offerman 2012). The tasks in many of the organizations are increasingly becoming interdependent, team-based(Bassford and Offerman 2012).Nonetheless, research on coworker support and employee job embeddedness has been very few. Results of the studies on coworker support and employee turnover have yielded inconsistent results. Some research has demonstrated that coworker support has a negative impact on turnover (Fisher, 1985), but more studies have found no relationship (Iverson \& Pullman, 2000; Mossholder et al 2005).It has also been claimed by researchers that coworkers generate a considerable impact on their fellow employees and work environments (Eder \& Eisenberger, 2008). Thus, recognizing this void in the literature the existing study contributes to the understanding of co-workers' interpersonal relationships by exploring co-worker support as a moderator affecting the link between work family conflict and job embeddedness. Employees have a more proximity with coworkers as compared to supervisors during their work life hence, the researchers have developed a model investigating (i) the impact of joint effects of work overload, work family conflict and family work conflict on job embeddedness (ii) the moderating effect of coworker support on the relationship between work overload, work family conflict and family work conflict on job embeddedness.

\section{Literature Review}

The first variable to that often boosts the family work conflict and work family conflict is work overload (Frone,Yardley, \& Markel, 1997; Parasuraman 1996). In objective terms work overload can be defined 
Work Overload, Work-Family Conflict, Family-Work Conflict and Their Effects on Job...

as a psychological stressor which is peril to an employee when an employee has ample of task to do and has too little time (Claessens et al 2004) frequently attributed as one of the job stressor (Robinson \& Griffiths2005). Another concept is of perceived workload which is associated to employees' viewpoint of objective work overload when they rely on thought of having many job tasks to do (Leiter and Schaufeli 1996) or inadequate time to culminate or conclude the task (Greenglass et al. 2003). Together, heavy workload, work family conflict and family work conflict are the causes for conflict in the work and family sphere (Deery, 2008).

The bidirectional constructs of work-family conflict are evident in the work-family literature (Frone 2003, Shockley and Singla 2011; Adams, King \& King, 1996; Neteymeyer et al., 1996; Haar 2004). By directional construct means that work demand impedes with family and similarly, family related responsibilities impede with work. Work-family conflict can be defined as "that type of interrole conflict in which a person is unable to fulfill family related responsibilities because of the job demands, time allocated to and stress/tension created by the job". Family-work conflict can be defined as "that type of interrole conflict in which a person is unable to fulfill job related responsibilities because of common demands, time allocated to and stress/tension created by family domain" (Netemeyer et al., 1996). One can have social support at work either from supervisor, coworker or both (Karatepe 2010). Social support imply "an interpersonal transaction that involves emotional concern, instrumental aid, information, or appraisal can be received from coworkers and supervisors in the workplace" (Karatepe 2010). Coworker support is a constituent of social support (Carlson \& Perrewe 1999). Job embeddedness consists of extensive group of psychological, social and financial aspects on employee retention. Basically, it is a web/net of job and immediate work environment in which an employee is engrained. Links, fit and sacrifice are the three dimensions of job embeddedness (Mitchell et al 2001). Associations among person, institution and other people (formal or informal) is links. Fit includes concept of perceived comfort with the organization and surrounding community. Finally, sacrifice refers to "the apparent cost of material or psychological benefits that may be lost by leaving a job" (Lee et al.,2004). Recent number of studies reveal that consequences of job embeddedness are reductions in turnover intention/voluntary turnover and increased levels of in-role and extra-role performances (Karatepe and Ngeche 2012).Very few researchers have suggested the basis for job embeddedness (Holtom et al., 2012; Ng and Feldman, 2011). Individual and/or organizational variables that impact employees on becoming embedded in their profession are compensation, growth opportunity, and supervisor support (Bergiel et al. 2009; Sun et al. 2011). In keeping with Ng and Feldman's (2011) study on managerial level, they revealed that contract non-replicability and social networking behaviors functioned as full mediators between internal locus of control and job embeddedness. Karatepe (2013) indicated work social support and high performance work practices as antecedents of job embeddedness and turnover intentions.

Plentiful studies have been carried out on work-family conflict sphere. Liu and Low (2011) found that time and strain are the highest reported reasons for both types of conflicts i.e. work-to-family and family-towork. Similar to this idea, Work-to-family conflict consist of lower levels of satisfaction with family and career, lower organizational commitment and attachment, greater aggression at home, and a variety of negative physiological and psychological health outcomes in case of eminent conflict (Eby et al. 2005). While, Shockley and Singla (2011) tried adding to the work-family literature by their study that family interference with work bring about job satisfaction rather than family satisfaction and work interference with family bring about more strongly the family satisfaction compared to job satisfaction. This is also consistent with Karatepe and Uludag (2008) research that marital satisfaction is reduced when there is family-work conflict and together these two sides strengthen turnover intention. In addition to this, Karatepe and Babar (2006) examined frontline employees of hotel in Jordan and established that family-work conflict had stronger relationship with turnover intention as compared to work-family conflict. Differing to this idea, Naeem et. al (2013) conducted a study in Pakistan and concluded that both had stronger relationship to employee turnover. Furthermore, Armstrong et al. (2007) carried out a study on women in IT about cause of work-family conflict on advancement and voluntary turnover through measures of managing family responsibility, work qualities, stress at work and work schedule flexibility. Researchers edify that work and family interaction has direct as well as indirect effect both on advancement opportunities and voluntary turnover.

A closely related piece of effort on moderators between work family conflict and satisfaction with career or profession by Martins et al (2002) inspected that moderators such as marital and parental status, individual's coworker, community and household can be taken. The authors measured the impact of coworkers in reducing the effect of work family conflict on satisfaction with profession or career through socioemotional support and found that it had moderating effects. Previous studies on industries other than hospitality industry have suggested that positive relationship exists between work-related stress and intention to leave (Bedeian et al. 1983, Grandey and Cropanzano 1999). On the other hand, researchers have also shown opposing results that work-family conflict is not associated with intention to quit in scientists and engineers in R\&D industry (DiTomaso 2009).

Analysis on stress and its consequence exhibit that many researchers have taken social support as undoubtedly the moderating variable (Visweswaran, Sanchez 1999; Seiger 2009; Karatepe 2010). As suggested 
Work Overload, Work-Family Conflict, Family-Work Conflict and Their Effects on Job...

by Morrison (2004) workplace relationships are based on inequality therefore informal relationship at work specifically with coworkers result in positive job satisfaction and organization commitment. Lambert at al (2010) contended that coworker support acts as a buffer to feelings of facing problems to solve job challenges. Therefore, support from coworkers makes the job a meaningful place to work. Lingarel \& Francis (2006) indicated that work family conflict and burnout is reduced when there is support from supervisor, coworker and organizational. The researchers measured support in terms of emotional aspect instead of practical aspect of support. As opposed to other researches, the independent effects of supervisor and coworker has not been able to affect work family conflict and burnout but together these both types of supports act as moderators of the link between work-family conflict and burnout.

Taking into account the above discussion, the research model is validated in Figure 1. Accordingly, the hypotheses can be derived as:

H1: A negative association exists between Work overload and job embeddedness

H2: A negative association exists between Work-family conflict and job embeddedness

H3: A negative association exists between Family-work conflict and job embeddedness

H4: Support of coworker moderates the association of work overload and job embeddedness

H5: Support of coworker moderates the association of work family conflict and job embeddedness

H6: Support of coworker moderates the association of family- work conflict and job embeddedness

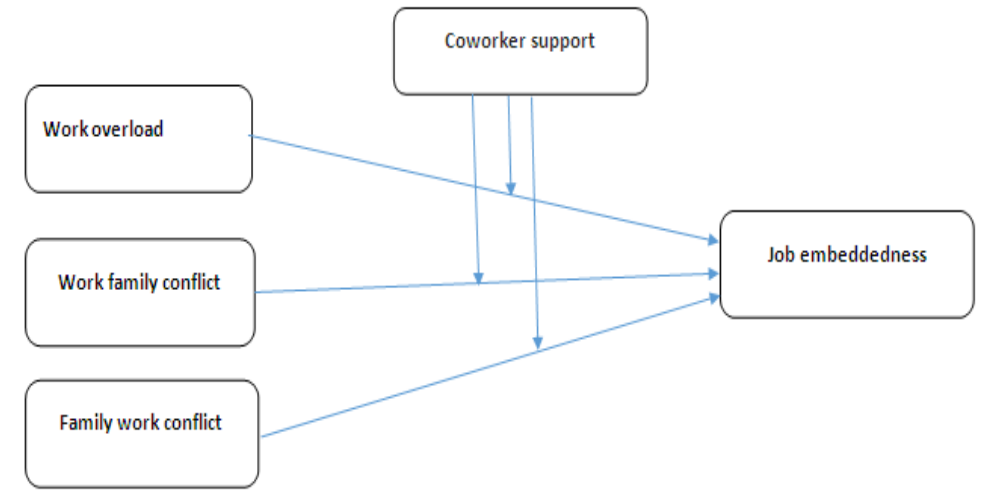

III. Research Methodology

The study was cross-sectional and causal in nature. 250 employees were chosen as respondents from banks in twin cities of Pakistan i.e. Rawalpindi and Islamabad. Employees were selected from Standard Chartered, Askari Bank Limited, United Bank Limited, Meezan Bank Limited and Faysal Bank Limited. Data was collected through questionnaire. Four items from Price (2001) were used to measure work overload. The items measuring work family conflict and family work conflict were taken from Netemeyer et al. (1996) consistent with other studies (e.g. Karatepe and Uludag, 2008). Seven items of job embeddedness were picked from Crossley et al. (2007) while coworker support items was measured by means of adapted scale of Settoon and Mossholder (2002) cited in Tews et. al (2013). Cronbach's Alpha of all variables was 0.70 giving an internal consistency of the scales.

\section{Data Analysis And Discussion}

Simple and multiple regression and Barren and Kenney test were used to assess data.

\subsection{Hypothesis Testing \\ Table 4.1 Multiple Regression Analysis \\ *dependent variable}

Table 4.2 Moderated Regression Analysis

\begin{tabular}{|l|l|l|l|}
\hline & \multicolumn{3}{|l|}{ Job embeddedness* } \\
\hline Independent Variables & Beta & $\mathrm{t}$ value & $\mathrm{p}$ value \\
\hline Work Overload & -.250 & -2.787 & .006 \\
\hline Work-family conflict & .013 & .140 & .889 \\
\hline Family-work conflict & -.174 & -2.296 & .042 \\
\hline
\end{tabular}


Work Overload, Work-Family Conflict, Family-Work Conflict and Their Effects on Job...

Model Summary

\begin{tabular}{|l|l|l|l|l|}
\hline Model & $\mathrm{R}$ & R Square & Adjusted R Square & Std. Error of the Estimate \\
\hline 1 & $.281^{\mathrm{a}}$ & .079 & .071 & .96369020 \\
2 & $.286^{\mathrm{b}}$ & .082 & .066 & .96651479 \\
\hline
\end{tabular}

a. Predictors: (Constant), Zscore(work_load)

b. Predictors: (Constant), Zscore(work_load), Mod_CW_WL

\begin{tabular}{|c|c|c|}
\hline & t-value & p-value \\
\hline Work overload*Coworker support & -0.558 & 0.578 \\
\hline
\end{tabular}

Table 4.3Moderated Regression Analysis

Model Summary

\begin{tabular}{|l|l|l|l|l|}
\hline Model & $\mathrm{R}$ & R Square & Adjusted R Square & Std. Error of the Estimate \\
\hline 1 & $.208^{\mathrm{a}}$ & .043 & .035 & .98220146 \\
2 & $.233^{\mathrm{b}}$ & .054 & .038 & .98085124 \\
\hline
\end{tabular}

a. Predictors: (Constant), Zscore(familywork_conflict)

b. Predictors: (Constant), Zscore(familywork_conflict), Mod_CW_FWC

\begin{tabular}{|c|l|c|}
\hline & t-value & p-value \\
\hline Family work conflict*Coworker support & -1.151 & 0.252 \\
\hline
\end{tabular}

The first hypothesis predicts that a negative association between work overload and job embeddedness is observed to be true. The regression analysis indicated that work overload and job embeddedness have a negative association with the strength of $25 \%$ as shown in table 4.1 . Second hypothesis predicts work family conflict has a negative association to job embeddedness was found to be false through the regression analysis which shows no influence of work family conflict reducing job embeddedness. H3 suggests that negative association exists between family work conflict and job embeddedness. The regression analysis shows that work family conflict has a negative relationship with job embeddedness with a strength of $17.4 \%$. The results were in line with the findings of Karatepe and Badar (2006), Karatepe (2013) and Boyar et. al (2003).

Moderated regression was used for applying moderation of coworker support on work overload and job embeddedness. According to table 4.2, since the change in $\mathrm{R}$ square did not increase as well as the $\mathrm{p}$ value of moderator could not found significant, H4 was rejected. Hypothesis 5 which stated that support of coworker moderates the association of work-family conflict and job embeddedness was also rejected due to the rejection of first hypothesis. Sixth hypothesis stated that support of coworker moderates the bond of family-work conflict and job embeddedness was also rejected due to insignificant change in $\mathrm{R}$ square as well as $\mathrm{p}$-value of the moderator. The results were in line with the finding of Haar (2004) and Mossholder et al (2005).

\subsection{Conclusion}

The main purpose of this study was to explore the linkage of work overload, work-family conflict and family-work conflict and job embeddedness of bank employees. It was found that:

- Work overload has a negative relationship with job embeddedness whereas coworker support does not moderate the relationship of work overload and job embeddedness.

- Work-family conflict has been found to have no relationship with job embeddedness. Therefore, moderation of coworker support on this relationship could not be established.

- Family-work conflict has a negative relationship with job embeddedness. However, coworker support could not moderate the relationship of family-work conflict and job embeddedness. 
Work Overload, Work-Family Conflict, Family-Work Conflict and Their Effects on Job...

\section{References}

[1]. Adams, G. A., King, L. A., \& King, D. W. (1996). Relationships of job and family involvement, family social support, and workfamily conflict with job and life satisfaction. Journal of Applied Psychology.Vol. 81 No. 4

[2]. Aslam, N. Imran R. Anwar, M., Hameed, Z., Kafayat, A. (2013) The Impact of Work Family Conflict on Turnover Intentions: An Empirical Evidence from PakistanWorld Applied Sciences Journal Vol. 24 No. 5

[3]. Armstrong, D. J., Riemenschneider, C. K., W. A. Myria, Reid, M. F. (2007).Advancement, voluntary turnover and women in IT:A cognitive study of work-family conflictJournal of Information \& managementVol. 44

[4]. Basford T. E.,AND Offermann L. R.(2012). Beyond leadership: The impact of coworker relationships on employee motivation and intent to stayJournal of Management \& OrganizationVol.18 no.6

[5]. Bedeian , A . G ., Mossholder, K. W . and Armenakis, A . A . ( 1983 ) Role perception-outcome relationships: Moderating effects of situational variables. Human Relations

[6]. Bergiel, E.B., Nguyen, V.Q., Clenney, B.F. and Taylor, G.S. (2009), "Human resource practices, job embeddedness and intention to quit", Management Research News, Vol. 32 No. 3.

[7]. Boyar, S. L., Maertz C. P., Pearson, A. W., Keough, S. (2003). Work-Family Conflict: A Model Of Linkages Between Work And Family Domain Variables And Turnover Intentions.Journal of Managerial Issues. Vol. 15, No. 2

[8]. Byron, K. (2005). A meta-analytic review of work-family conflict and its antecedents. Journal of Vocational Behavior Vol. 67

[9]. Carlson, D.S. and Perrewe', P.L. (1999), "The role of social support in the stressor-strain relationship: an examination of workfamily conflict", Journal of Management, Vol. 25 No. 4

[10]. Claessens B. J., van Eerde W., Rutte C. G., Roe R. A.(2004). Planning behavior and perceived control of time at work. Journal of Organizational Behavior, Vol.26

[11]. Crossley, C.D., Bennett, R.J., Jex, S.M. and Burnfield, J.L. (2007), "Development of a global measure of job embeddedness and integration into a traditional model of voluntary turnover", Journal of Applied Psychology, Vol. 92 No. 4

[12]. Chiaburu, D. S. (2010) "The social context of training: coworker, supervisor, or organizational support?", Industrial and Commercial Training, Vol. 42 No. 1

[13]. Deery, M. (2008), "Talent management, work-life balance and retention strategies", International

[14]. Journal of Contemporary Hospitality Management, Vol. 20 No. 7,

[15]. DiTomaso, N., Post C., Fariis G. F., Cordero R. (2009). Work-Family Conflict and Turnover Intentions Among Scientists and Engineers Working in R\&D. Journal of business and Psychology Vol. 24 No. 1

[16]. Eby, L. T., Casper, W. J., Lockwood, A., Bordeaux, C., \& Brinley, A. (2005). Work and family research in IO/OB: Content analysis and review of the literature (1980 -2002). Journal of Vocational Behavior,Vol. 66

[17]. Eder, P., \& Eisenberger, R. (2008). Perceived organizational support: Reducing the negative influence

[18]. of coworker withdrawal behavior. Journal of Management, vol. 34 No. (1)

[19]. Felps, W., Mitchell, T. R., Hekman, D. R., Lee, T. W., Holtom, B. C., \& Harman, W. S. (2009). Turnover

[20]. contagion: How coworkers' job embeddedness and job search behaviors influence quitting. Academy of

[21]. Management Journal, Vol. 52 No. (3)

[22]. Fisher, C. D. (1985). Social support and adjustment to work: A longitudinal study. Journal of Management, Vol. 11

[23]. Frone, M.R., Yardley, J.K., \& Markel. K.S. (1997). Developing and testing an integrative model of the work family interface. Journal of Vocational Behavior Vol. 50

[24]. Grandey, A . A . and Cropanzano, R . (1999). The conservation of resources model applied to work-family conflict and strain Journal of Vocational Behavior Vol. 54

[25]. Greenglass, E.R., Burke, R.J. and Moore, K.A. (2003), "Reactions to increased workload: effects on professional efficacy of nurses", Applied Psychology: An International Review, Vol. 52

[26]. Greenhaus, J. H., \& Powell, G. N. (2003). When work and family collide: Deciding between competing role demands. Organizational Behavior and Human Decision Processes, Vol. 90

[27]. Haar, J.M. 2004. "Work-family conflict and turnover intention: Exploring the moderation effects of perceived work-family support". New Zealand Journal of Psychology Vol. 33 No.1

[28]. Holtom, B.C., Burton, J.P. and Crossley, C.D. (2012), "How negative affectivity moderates the relationship between shocks, embeddedness and worker behaviors", Journal of Vocational Behavior, Vol. 80 No. 2

[29]. Ileas, R., Schwind, K. M., Wagner D. T., Johnson M. D., (2007). "When Can Employees Have a Family Life? The Effects of Daily Workload and Affect on Work-Family Conflict and Social Behaviors at Home" Journal of Applied Psychology, Vol. 92, No. 5 ,

[30]. Iverson, R. D., \& Pullman, J. A. (2000). Determinants of voluntary turnover and layoffs in an environment of repeated downsizing following a merger: An event history analysis. Journal of Management, Vol. 26

[31]. Karatepe, O. M., Baddar, L. (2006). An empirical study of the selected consequences of frontline employees' work-family conflict and family-work conflict

[32]. Karatepe, O.M. and Uludag, O. (2008), "Role stress, burnout and their effects on frontline hotel employees' job performance: evidence from Northern Cyprus", International Journal of Tourism Research, Vol. 10 No. 2

[33]. Karatepe, O. M. (2010). "The effect of positive and negative work-family interaction on exhaustion Does work social support make a difference?” International Journal of Contemporary Hospitality Management Vol. 22 No. 6, 2010

[34]. Karatepe, O. M. (2013). High-performance work practices, work social support and their effects on job embeddedness and turnover intentions International Journal of Contemporary Hospitality Management Vol. 25 No. 6

[35]. Karatepe, O.M. and Ngeche, R.N. (2012), "Does job embeddedness mediate the effect of work engagement on job outcomes? A study of hotel employees in Cameroon”, Journal of Hospitality Marketing and Management, Vol. 21 No. 4

[36]. Lingard, H.Francis, V. (2006). “Does a supportive work environment moderate the relationship between work-family conflict and burnout among construction professionals?" Construction Management and Economics, Vol. 24

[37]. Lambert, E. G., Altheimer I. and Hogan N. L. (2010) "Exploring the Relationship between Social Support and Job Burnout Among Correctional Staff" Criminal Justice and Behavior, Vol. 37 No. 11

[38]. Lee, T.W., Mitchell, T.R., Sablynski, C.J., Burton, J.P. and Holtom, B.C. (2004), "The effects of job embeddedness on organizational citizenship, job performance, volitional absences, and voluntary turnover", Academy of Management Journal, Vol. 47

[39]. Leiter, M.P. and Schaufeli, W.B. (1996), “Consistency of the burnout construct across occupations", Anxiety, Stress, and Coping, Vol. 9

[40]. Liu, Y. J. and Low, S. P. (2011). Work-family conflicts experienced by project managers in the Chinese construction industry. International Journal of Project Management, Vol. 29 No. 2 
Work Overload, Work-Family Conflict, Family-Work Conflict and Their Effects on Job...

[41]. MARTINS, L. L., Eddleston K. A., Veiga, J. F. (2002)."Moderators of the Relationship between Work-family Conflict and Career Satisfaction"Academy of Management Journal, Vol. 45

[42]. Masuda, D. A., Poelmans, A.Y. S., Allen, D. T., Spector, E. P., Lapierre, M. L., Cooper, L. C., Abarca, N., Brough, P., Ferreiro, P., \& Fraile, G. (2012). Flexible Work Arrangements Availability and their Relationship with Work-to-Family Conflict, Job Satisfaction, and Turnover Intentions: A Comparison of Three Country Clusters. The International Association of Applied Psychology. Vol. 61 No.1.

[43]. Messmer-Magnus J., Viswesvaran C. (2009)“The role of the coworker in reducing work-family conflict: A review and directions for future research" Journal of Pratiques psychologiques Vo. 15 No. 2

[44]. Michailidis, M., Georgiou,Y. (2005). Employee occupational stress in banking. Journal of prevention, Assessment and Rehabilitation, Vol. 24

[45]. Mitchell, T.R., Holtom, B.C., Lee, T.W., Sablynski, C.J. and Erez, M. (2001), "Why people stay: using job embeddedness to predict voluntary turnover", Academy of Management Journal, Vol. 44 No. 6

[46]. Morrison R. (2004). "Informal Relationships in the Workplace: Associations with Job Satisfaction, Organizational Commitment and Turnover Intentions"New Zealand Journal of Psychology Vol. 33 No. 3

[47]. Mossholder, K. W., Settoon, R. P., \& Henagan, S. C. (2005). A relational perspective on turnover: Examining structural, attitudinal, and behavioral predictors. Academy of Management Journal, Vol. 48

[48]. Netemeyer, R. G., Boles, J. S., \& McMurrian, R. (1996). Development and validation of work-family conflict and family-work conflict scales. Journal of Applied Psychology, Vol. 81

[49]. Ng, T.W.H. and Feldman, D.C. (2011), "Locus of control and organizational embeddedness", Journal of Occupational and Organizational Psychology, Vol. 84 No. 1, pp. 173-190.

[50]. Parasuraman, S., Purohit, Y. S, Godshalk, V.M., \& Beutell, N.J. (1996). Work and family variables, entrepreneurial career success, and psychological well-being, Journal of Vocational Behavior, Vol. 48

[51]. Price, J.L. (2001), "Reflections on the determinants of voluntary turnover", International Journal of Manpower, Vol. 22 No. 7,

[52]. Robinson, O. and Griffiths, A. (2005), "Coping with the stress of transformational change in a government department", Journal of Applied Behavioral Science, Vol. 41

[53]. Sagie, A., Birati, A., \& Tziner, A. (2002). Assessing the costs of behavioral and psychological withdrawal: A new model and an empirical illustration. Applied Psychology: An International Review, 51,

[54]. Seiger, C. P., Wiese, B. S. (2009). Social support from work and family domains as an antecedent or moderator of work-family conflicts?Journal of Vocational Behavior, Vol.75

[55]. Settoon, R. P., \& Mossholder, K. W. (2002). Relationship quality and relationship context as antecedents of person- and taskfocused interpersonal citizenship behavior. Journal of Applied Psychology, Vol. 87

[56]. Shockley, K. M., and Singla, N. (2011). "Reconsidering Work--Family Interactions and Satisfaction: A Meta-Analysis" Journal of Management

[57]. Sun, T., Zhao, X.W., Yang, L.B. and Fan, L.H. (2011), “The impact of psychological capital on job embeddedness and job performance among nurses: a structural equation approach”, Journal of Advanced Nursing, Vol. 68 No. 1

[58]. Tews, M. J., Michel, J. M. Ellingson, J. E. (2013). The Impact of Coworker Support on Employee Turnover in the Hospitality Industry.Journal of Group \& Organization Management, Vol. 1 Iss:24

[59]. Viswesvaran, C., Sanchez, J.I. and Fisher, J. (1999), "The role of social support in the process of work stress: a meta-analysis", Journal of Vocational Behavior, Vol. 54 No. 2

[60]. Zhang, M., Fried, D. D., Griffeth R. w. (2012). A review of job embeddedness: Conceptual, measurement issues, and directions for future research. Journal of Human Resource Management Review 